
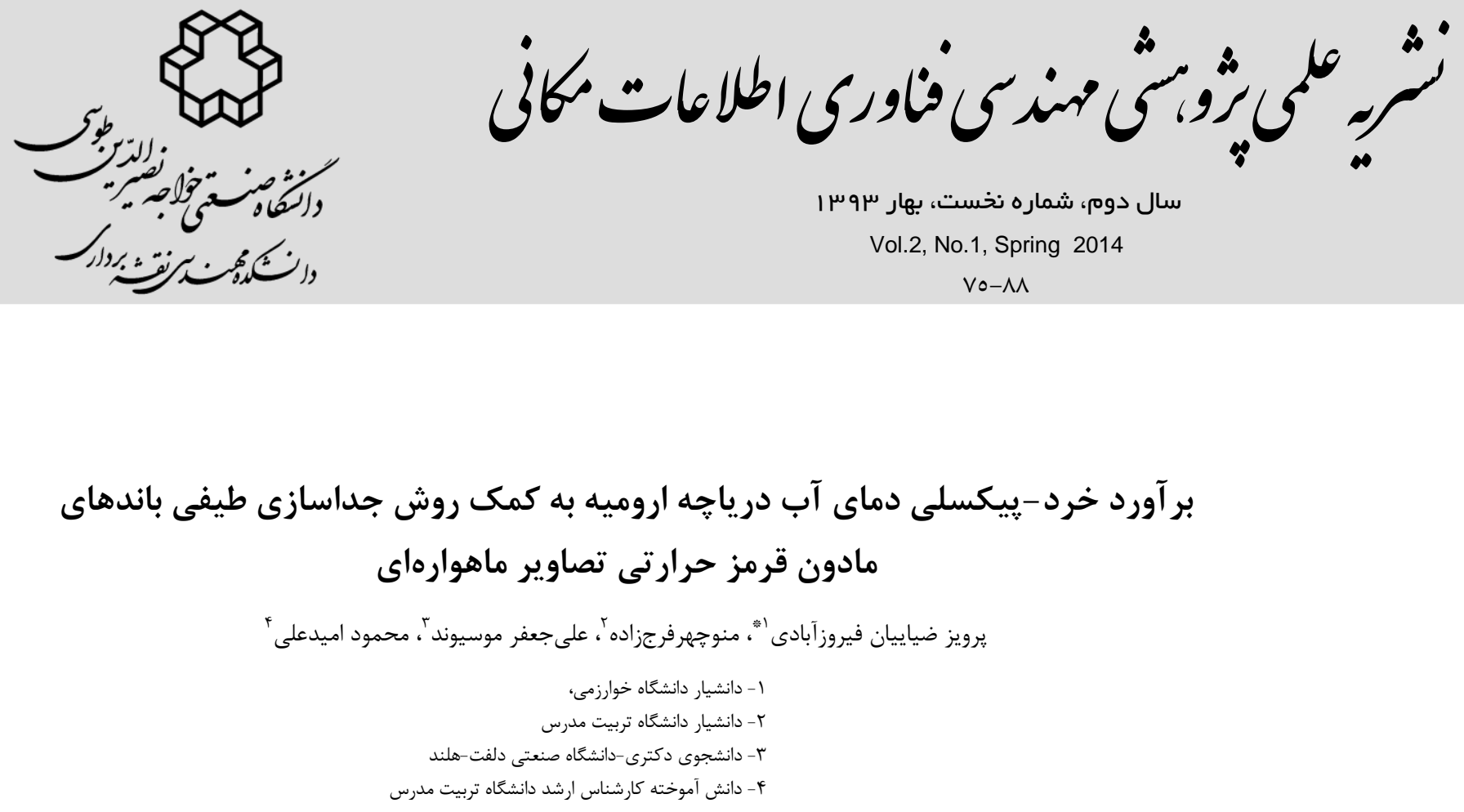

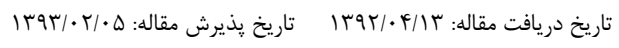

جكيده

دماى آب يك شاخص مهم محيطى در مطالعه آبراهه ها، رودخانه ها ودرياجه هاست، همجنين اهميت زيادى در مديريت منابع طبيعى و

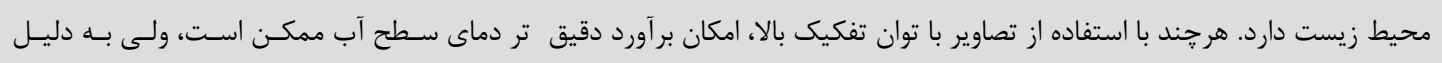

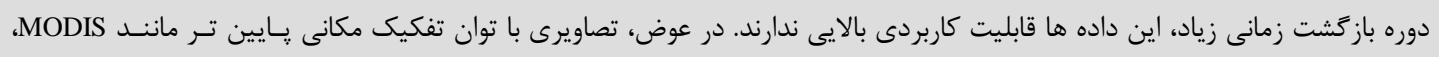

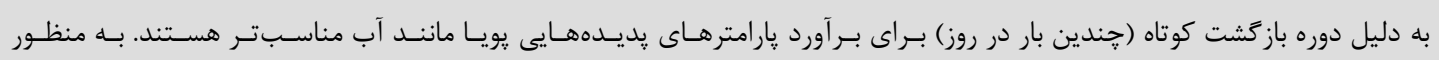

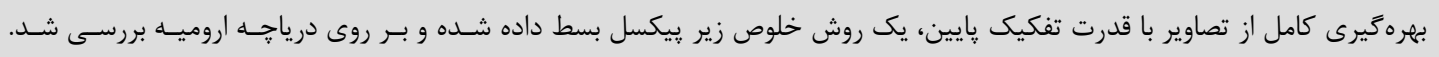

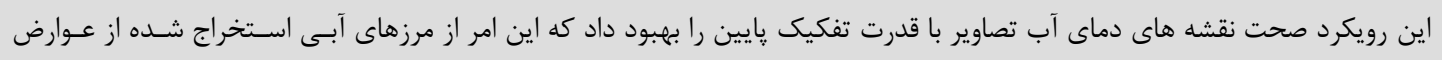

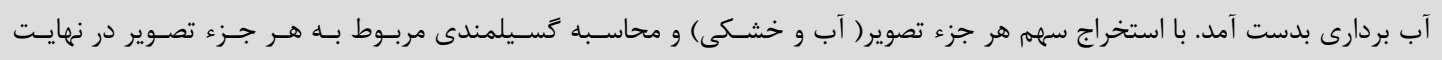

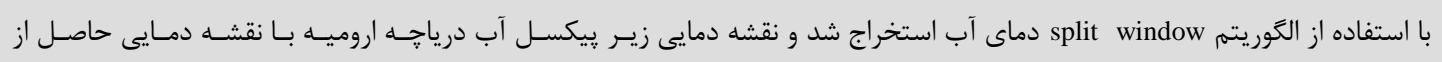

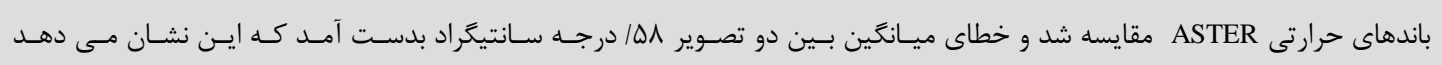
نتيجه مطلوبى حاصل شده است. كليدوازهها: دماى آب، MODIS ASTER ، بيكسل مبنا، جداسازى طيفى. 


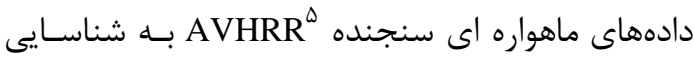

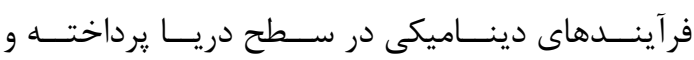
الكوى جريانات جرخندى در منطقه را نشان دادند. [ب] اوزج وهمكاران توزيـع ميـانكين سـاليانه دمـاى سطحح

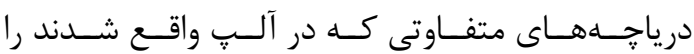

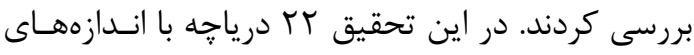

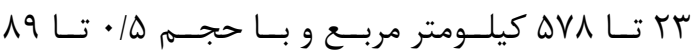

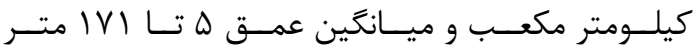

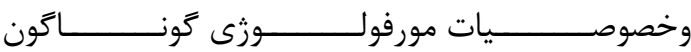
مورد بررسى قرار كرفتند. [هـ]

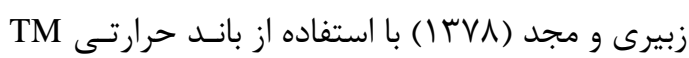

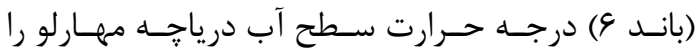
محاسبه كردند. در اين مطالعه با توجه بـهـ بانـد مـادون

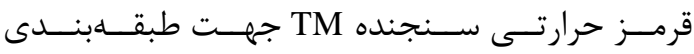

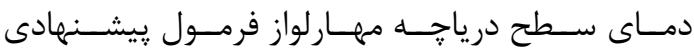

متخصصين دانشخاه يردو، استفاده شده است. [ع] با استفاده از سنجنده AVHRR نقشه دماى سطح دريا، در منطقه خليج فارس بررسى و بـين نقشـه حاصـله از

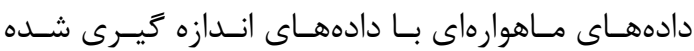
بر روى دريا رابطه اى معنى دراى به دست آمده اسـت.

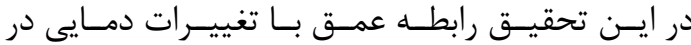

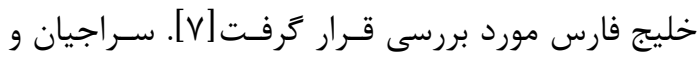

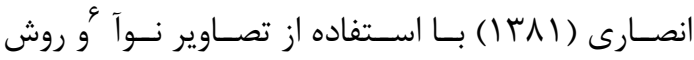

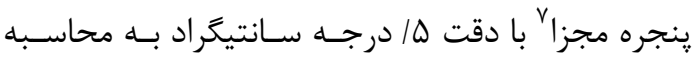

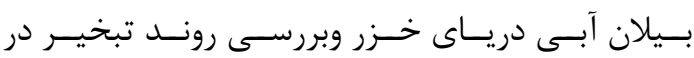
سطح درياجه يرداختند.

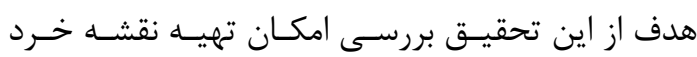

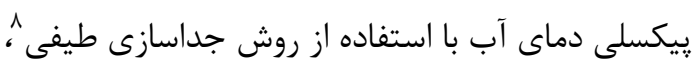

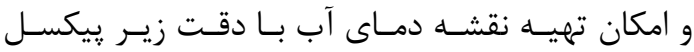
در منطقه مورد مطالعـه مسىباشـد. و دقـت نقشـهـــاى

5 Advanced Very High Resolution Radiometer 6 NOAA

7 spilt window

8 sub-pixel spectral unmixing
| - 1- (- مقدمه

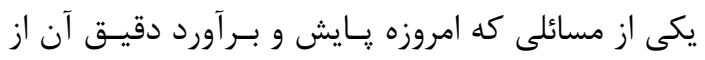

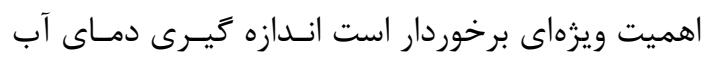
است. دماى آب يك شاخص مهـهم محيطى در مطالعـه

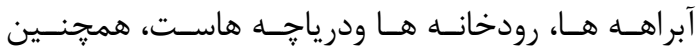

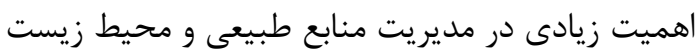
دارد. با توجه به اهميت دماى سطح آب استخراج شـده

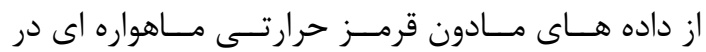

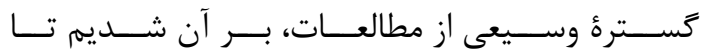

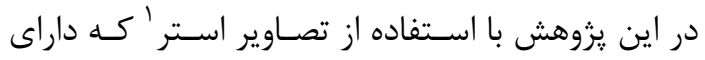

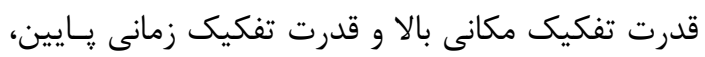
و بالعكس تصاوير مديس با قدرت تفكيك مكانى پايين اما در عوض داراى قدرت تفكيـك زمـانى بـالا (يـك يـا

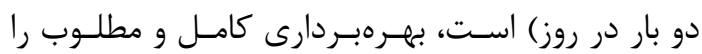

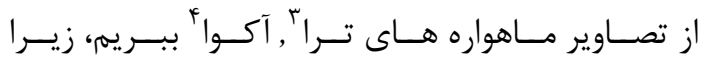
در ايـن مطالعـهـ هــم از قـدرت تفكيـك مكـانى بـالاى

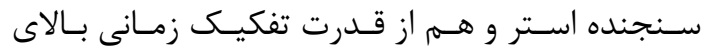

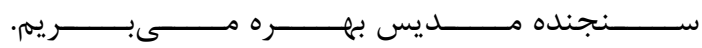
و به منظور جنين مطالعهاى از تكنيك خلوص طيفى در

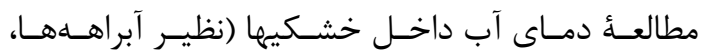
رودخانه ها ودرياجهها) استفاده مى كنيم.

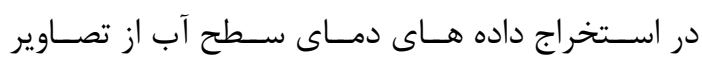

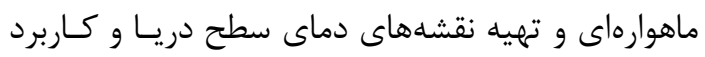
آن در توسعه صنعت ماهيخيرى تحقيقى بوسيله كودا و

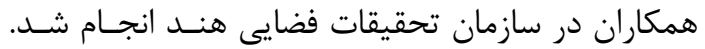

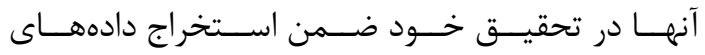

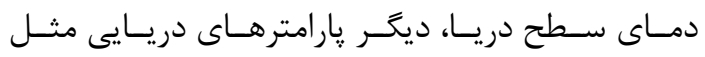

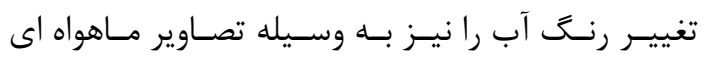

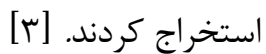
در دريــاى خــزر ســـر و همكــاران بــا اســتفاده از 
وجود دارد. در اينجا از كَيلمندى پيكسلهاى خالص و

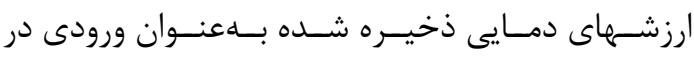

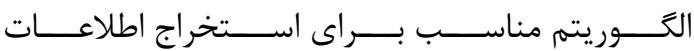
دماى زير קيكسل استفاده مىشود.

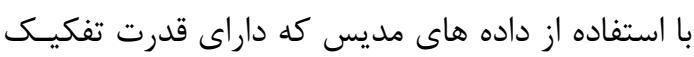

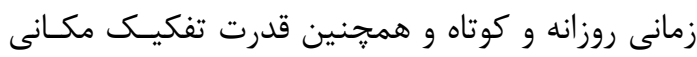

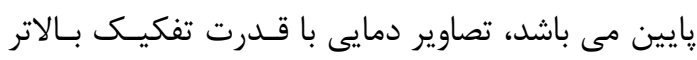

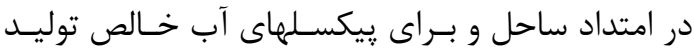

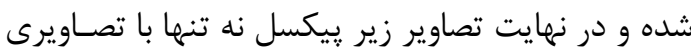

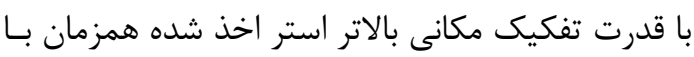

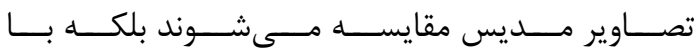

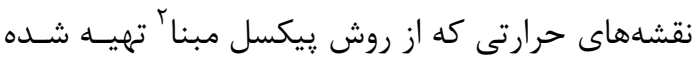

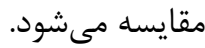

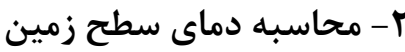

داشتن دماى سطح زمين و نقشه يوشش زمينى، ما را در

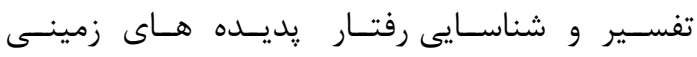
كمك مى كند. محاسبه ايـن قـارامتر از طريـق بانـدهاى

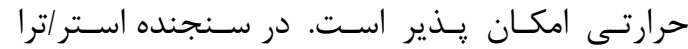

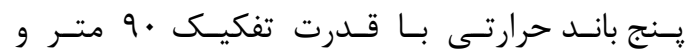

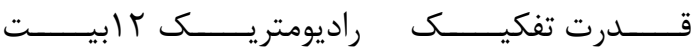

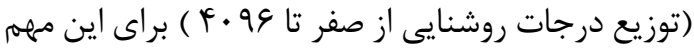

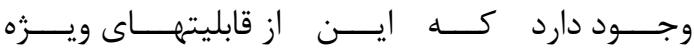

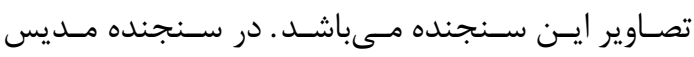
سه باند براى اندازهيرى دماى سطح آب با يك NEAT

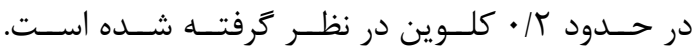

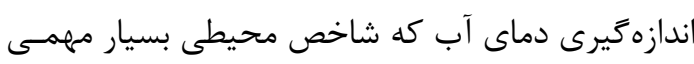

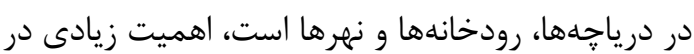

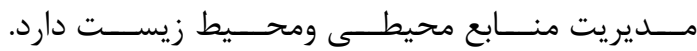
براى مطالعه تغييرات اقليمى، هيدرولوزيكى، اكولوزيكى

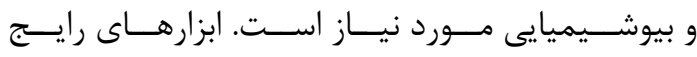

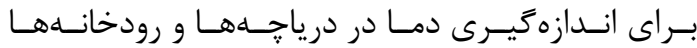

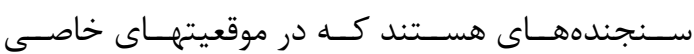

2 pixel base
بدست آمده از تصاوير با قدرت تفكيك فضايى يايين بـا

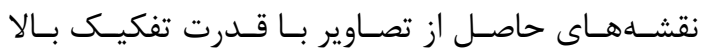

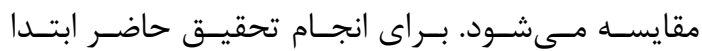

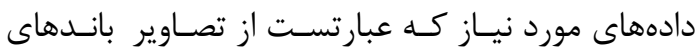
حرارتى مديس از ماهواره ترا مربوط به منطقه مورد نظر

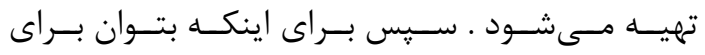
تهيه نقشه دماى سطحى آب مورد استفاده قرار داد بايد

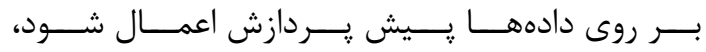
دماهاى استخراج شده از با ند هاى حرارتى را نمى دـــوان

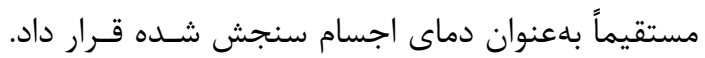

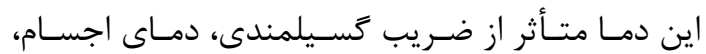
اتمسفر وخطاهاى مربوط به سيستم سنجش است. لـذا קيش يردازشهاى لازم تصحيح هندسى، راديومتريكى و

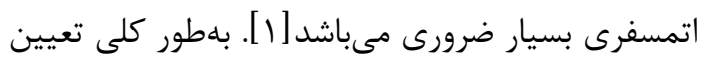

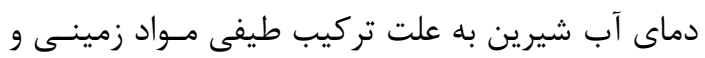

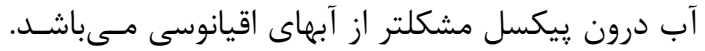

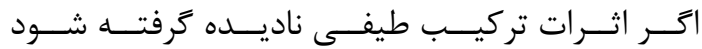

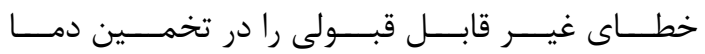

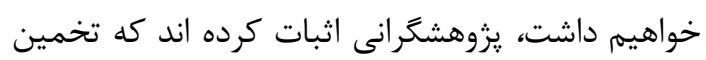
دماهاى زير يِيكسل ممكن اسـت بوسـيله تكنيـكهـاى تحليل طيفى با حل معادله راديـانس بيكسـل مخـتلط

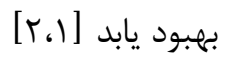

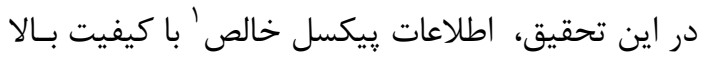

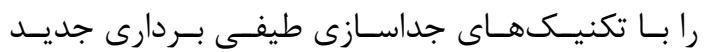

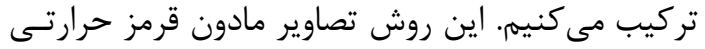

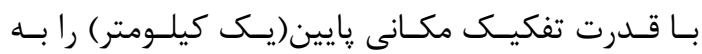

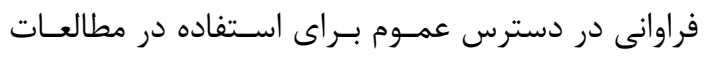

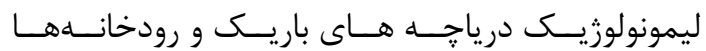

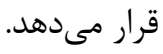
مسلم است كه جندين الكَوريتم معتبر براى جداسـازى

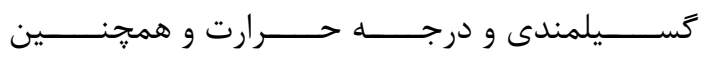
الكَوريتم تصحيح اتمسـفرى بـراى ييكسـلهاى خـالص درجات

1 Pure pixel 


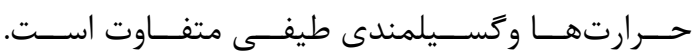
درجه تعميم اجزاى بيكسل يا اعضاى مرجع به كاربرد و NEAT منابع طيفى در دسترس مى باشد ( براى مثـال

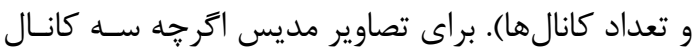
بـراى مطالعـات زمسين وجــود دارد (كانـالهــاى TIR rس، اس وq r) محصــول MOD11 مــاديس فقـط بــراى

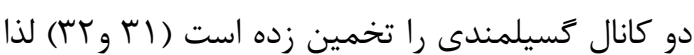

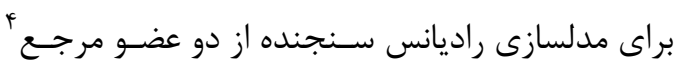

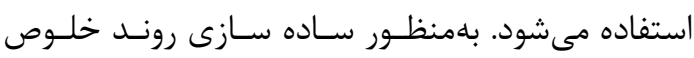

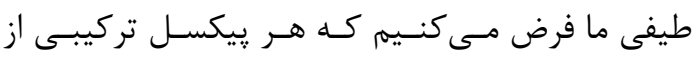

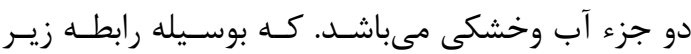
مدل شده است. رابطه (r)

$$
L_{k s}=\tau_{k}\left[f_{1} \varepsilon_{k 1} B_{k}\left(T_{1}\right)+f_{2} \varepsilon_{k 2} B_{k}\left(T_{2}\right)\right]
$$

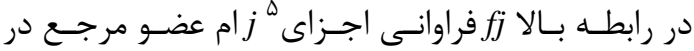

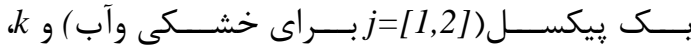

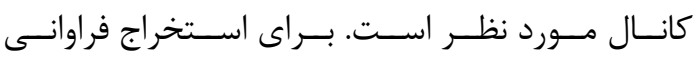
ييكسلهاى آب وخشكى نقشهى بــردارى درياجـهـ را بـهـ

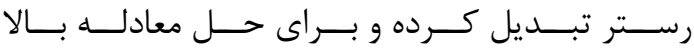
استفاده مى كنــيم. در نهايـت بـا داشـتن اطلاعـات بـالا براى استخراج حرارت زير بيكسل استفاده مى كنيم.

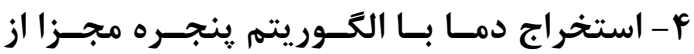
دادهاى استر

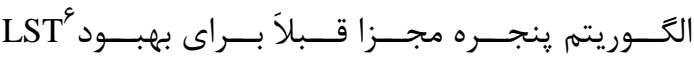

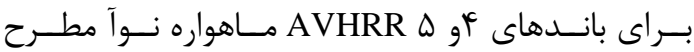

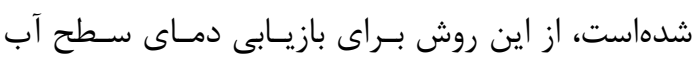

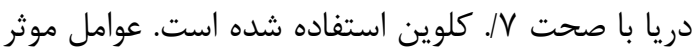
زيادى نظير: انتخاب روش انتقال راديانس، ضريب جذب

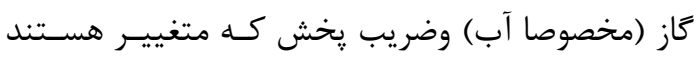

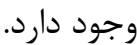

3 Thermal infra red

4 Endmember

5 fraction

6land surface temprature
نصب شدهاند كه تنها دماهاى محلى را گزارش مى كنند. از طرفى دستيابى به يك تعادل مناسب مـابين يوشـش مكانى و زمانى در اندازهزيـرى دمـا بـه وسـيله تصـاوير مادون قرمز حرارت ماهواره اي مى تواند مشـكل باشـد.

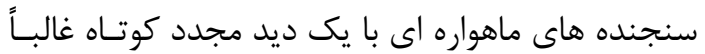

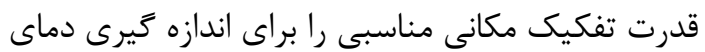
درياجهها و رودخانهها و آبراهلها را فـراهم نمسى كنـــد. (براى مثال تصاوير حرارتى سنجنده مـديس) همجنــين

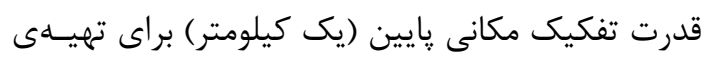

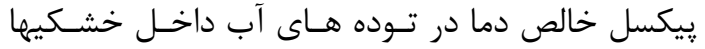
نامناسـب اسـت لـذا در ايـن تحقيـق يـــ روش بـراى

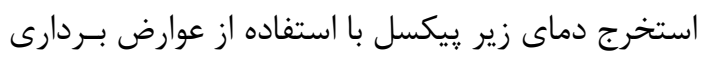
آب و تكنيك خلوص طيفى استفاده مىشود.

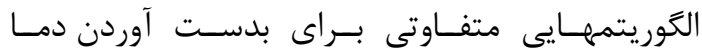

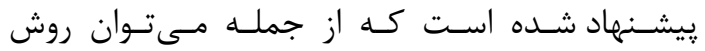

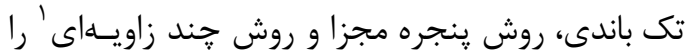

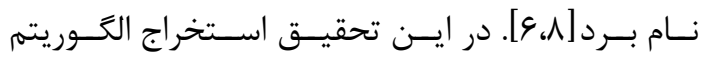

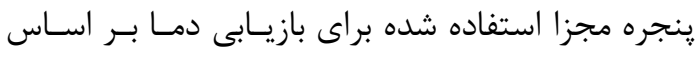

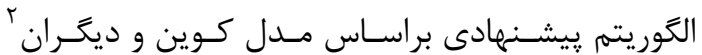

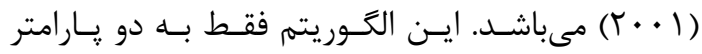

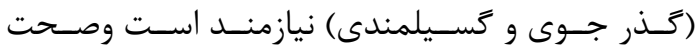
اين الغوريتم خيلى بالا ست. [1]

\section{r- تئورى استخراج دماى زير ييكسل}

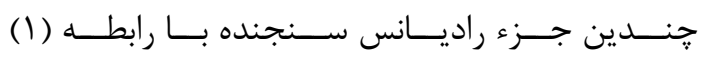
مدل شدهاند.

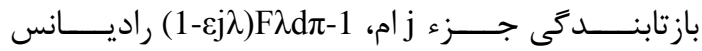

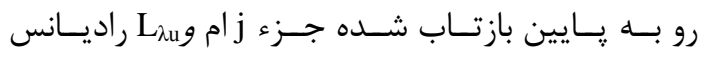

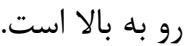

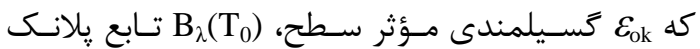
دماى مؤثر سـطح آب اسـت. راديـانس كسـيل شــده از

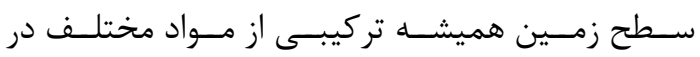

1 Multi Angle Method

2 Qin et al 


$$
L_{k s}=\int_{0}^{\infty} \phi_{k, \lambda}\left[\tau_{\lambda}\left(\sum_{j}^{n} \varepsilon_{j \lambda} B_{\lambda}\left(T_{j}\right)+\frac{\left(1-\varepsilon_{j \lambda}\right) F_{\lambda d}}{\pi}\right)+L_{\lambda u}\right] d \lambda
$$

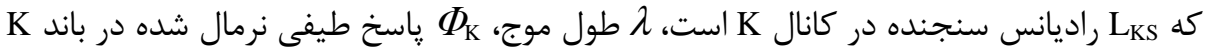
$\tau_{\lambda}$

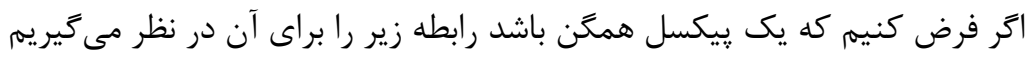

$$
L_{k s}=\int_{0}^{\infty} \phi_{k, \lambda}\left[\tau_{\lambda}\left(\varepsilon_{0 \lambda} B_{\lambda}\left(T_{0}\right)+\frac{\left(1-\varepsilon_{0 \lambda}\right) F_{\lambda d}}{\pi}\right)+L_{\lambda u}\right] d \lambda
$$

(Y) رابطه (1)

تعلـق مسى كيــرد. در واقـع خطــيـى كـهـ ناشسى از

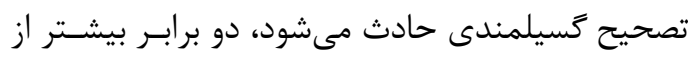

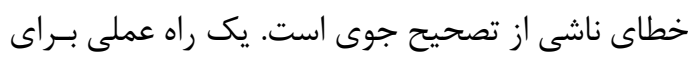

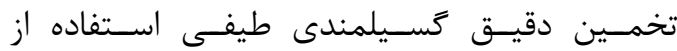

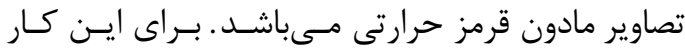

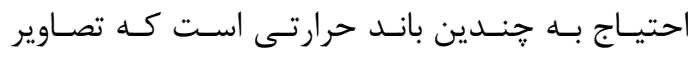

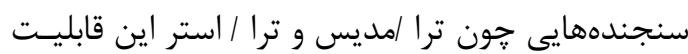
[ا دارند[9].

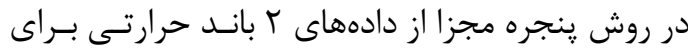

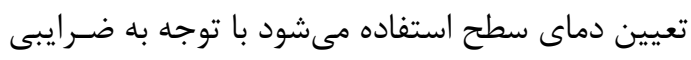

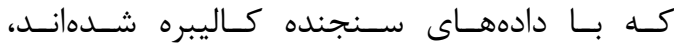
روابط تعريف شدهاى وجود دارد كه بايد با توجه به آنهـا

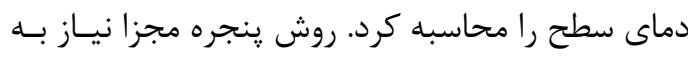
قابليت عبور جوى شار تابشى دارد [9]

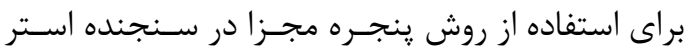

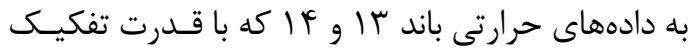
راديومترى كا بيتى برداشت مى شود، نياز است و مراحل

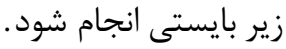

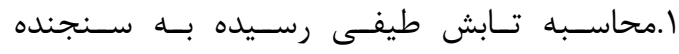
W/M2.ST:1

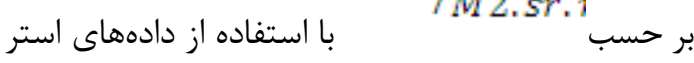

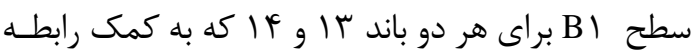

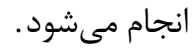

رابطه (a)

$\mathrm{L} 13=(\mathrm{DN} 13-1) \cdot 0.005693, \mathrm{~W} / \mathrm{m} 2 . \mathrm{sr} . \mathrm{m} \mu$

رابطه (9)

$\mathrm{L} 14=(\mathrm{DN} 14-1) \cdot 0.005225, \mathrm{~W} / \mathrm{m} 2 . \mathrm{sr} . \mathrm{m} \mu$

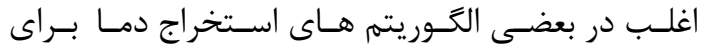

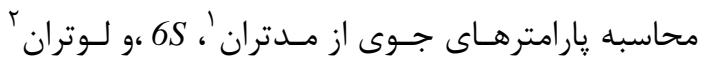

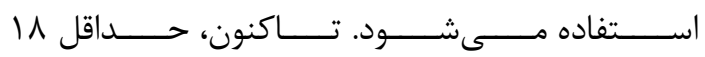

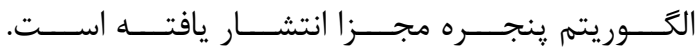
الكَوريته ينجره مجزا مىتواند بصورت زير نوشته شود: $\mathrm{T}_{\mathrm{S}}=\mathrm{T}_{4}+\mathrm{A}\left(\mathrm{T}_{4}-\mathrm{T}_{5}\right)+\mathrm{B}$ رابطه (i)

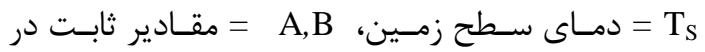
معادله، Th

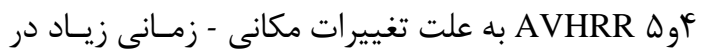

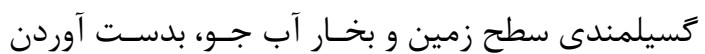

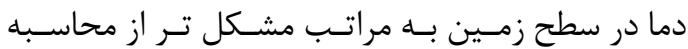

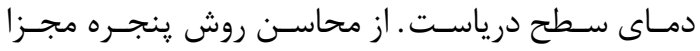

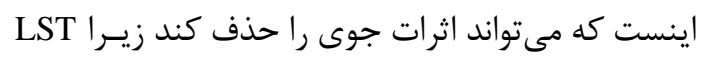

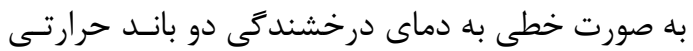

وابسته است. [9]

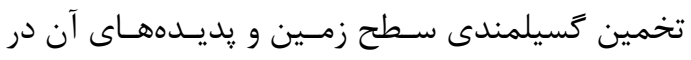
مقيـاس كلى و جهـانى بــراى اسـتفاده در الخـوريتم ينجره مجزا خيلى راحت نيست . روشهاى جندى بـ بـراى

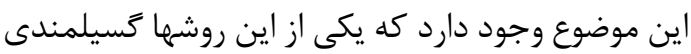
را به NDVI مرتبط مى كند [9]. روش ديكر، گسيلمندى را در ارتباط با اطلاعات يوشش

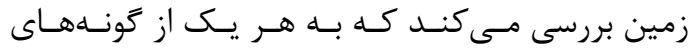

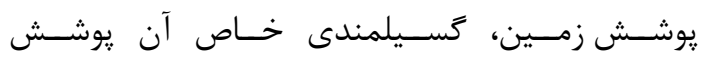

\section{MODTRAN}

2 LOWTRAN

3 Normalized Difference Vegetation Index 


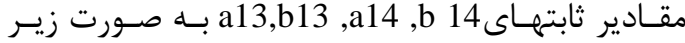

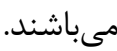

$a_{13=} 0.146162$

$\mathrm{b}_{13}=33.428610$

$a_{14=} 0.132836$

$\mathrm{b}_{14}=30.219316$

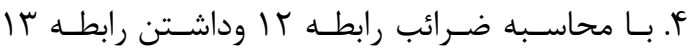
مى توان دماى سطح T T ا محاسبه كرد.

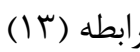

$\mathrm{TS}=\frac{\left[C_{14} \cdot\left(B_{1 \mathrm{a}}+D_{1 \mathrm{a}}\right)-C_{1 \mathrm{a}} \cdot\left(D_{14}+B_{1}\right.\right.}{\left(C_{14} \cdot A_{1 \mathrm{a}}-C_{1 \mathrm{a}} \cdot A_{14}\right)}$

ساير مقادير مورد نيـاز بــراى محاسـبه دمـاى سـطحى شامل گسيلمندى و قابليت عبور جو مى باشد. در مورد كسيلمندى از آنجايى كه هدف ما تخمين دماى سـطح

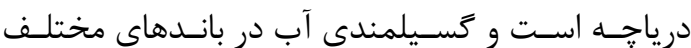

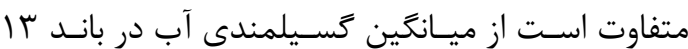

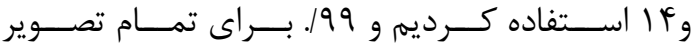
در نظر كرفته شد. قابليت عبور جو با استفاده از روابسط

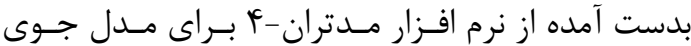

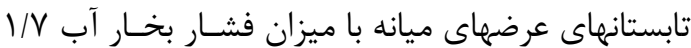
كرم بر سانتيمتر مربع با رابطه:

$\tau 13=-0.129086 W+1.056086$

رابطه (f)

$\tau 14=-0.150892 W+1.078407$

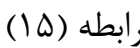

محاسـبه شــد و مقــادير $\tau_{14}=\tau_{13}=8366398$ و

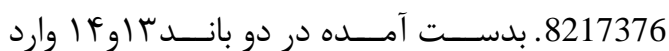
مدل ترديد. بهطور كلى، پارمترهاى محاسبه شده بـراى

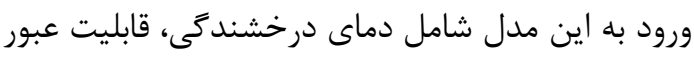
جو و كسيلمندى مىباشد.

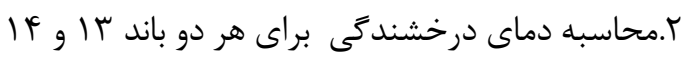

طبق رابطه

(V) رابطه

$\mathrm{T} 13=$

$\mathrm{C}_{2}$

$\left(0.0000106 \cdot \ln \left(\frac{C_{1}}{0.0000106^{5} \cdot L_{13} \cdot 10^{6}}+1\right)\right)$

(ᄉ) (1ابطه

$\mathrm{T} 14=$

$C_{2} /\left(0.0000113 \cdot \ln \left(\frac{C_{1}}{0.0000113^{5} \cdot L_{14} \cdot 10^{6}}+1\right)\right)$

كه ضرايب C1,C2 به صورت زير تعريف مىشوند

(9) رابطه

$\mathrm{C} 1=1.19104356 .10-16 \quad(\mathrm{wm} 2)$

رابطه (••)

$\mathrm{C} 2=1.43876869 .10-2 \quad(\mathrm{wK})$

Tr. A13, B13, C13,D13, A14,B14, محاسبه مقــادير C14,D14 مقادير محاسبه شده بـراى T13, T14 را در روابـط زيـر A13, B13, C13,D13, A14,B14, وارد كرده تا ضرايب

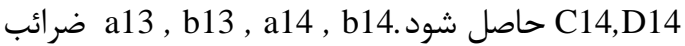
ثابتى هستند كه مقادير آنها در زير آورده شده است.

رابطه (1)

$\mathrm{A} 13=\mathrm{a}_{13} \cdot \varepsilon_{13} \cdot \tau_{13}$

$\mathrm{B} 13=\mathrm{a}_{13} \cdot \mathrm{T}_{13}+\mathrm{b}_{13} \cdot \varepsilon_{13} \cdot \tau_{13}-\mathrm{b}_{13}$

$\mathrm{C} 13=\left(1-\tau_{13}\right) \cdot\left[1+\left(1-\varepsilon_{13}\right) \cdot \tau_{13}\right] \cdot \mathrm{a}_{13}$

D13 $=\left(1-\tau_{13}\right) \cdot\left[1+\left(1-\varepsilon_{13}\right) \cdot \tau_{13}\right] \cdot b_{13}$

رابطه (T)

$\mathrm{A} 14=\mathrm{a}_{14} \cdot \varepsilon_{14} \cdot \tau_{14}$

$\mathrm{B} 14=\mathrm{a}_{14} \cdot \mathrm{T}_{14}+\mathrm{b}_{14} \cdot \varepsilon_{14} \cdot \tau_{14}-\mathrm{b}_{14}$

$\mathrm{C} 14=\left(1-\tau_{14}\right) \cdot\left[1+\left(1-\varepsilon_{14}\right) \cdot \tau_{14}\right] \cdot \mathrm{a}_{14}$

D14 $=\left(1-\tau_{14}\right) \cdot\left[1+\left(1-\varepsilon_{14}\right) \cdot \tau_{14}\right] \cdot b_{14}$ 


\section{برآورد خرد-يقيكسلى دماى آب درياجه اروميه...}

يرويز ضيائيان فيروز آبادى و همكار

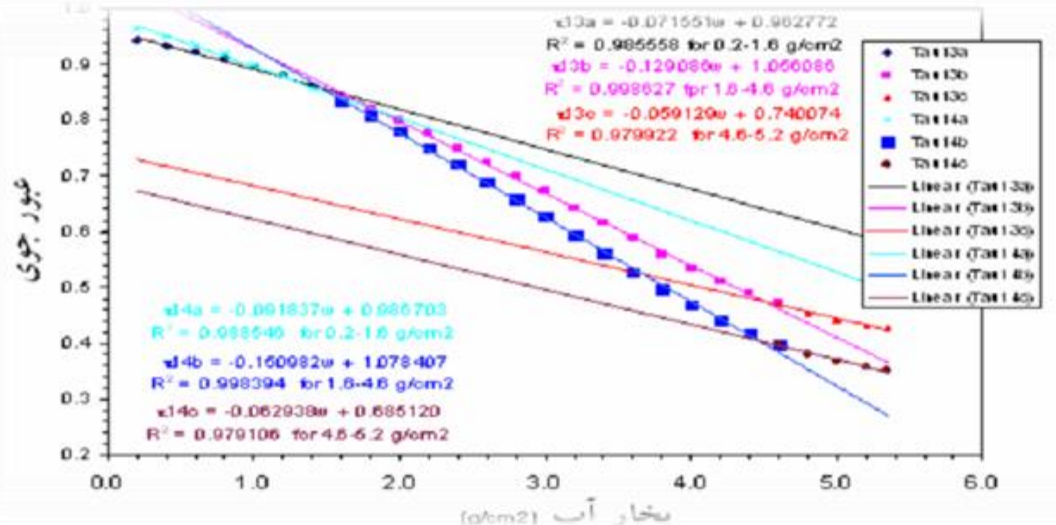

شكل ا: نمودار ميزان قابليت عبور جو براى مقادير مختلف بخار آب جو

به دادههاى حرارتى باند آ و r كس كه با قـدرت تفكيـك

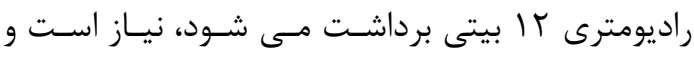

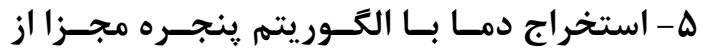

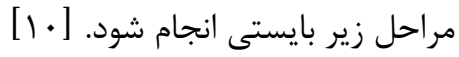
دادههاى مديس براى استفاده از روش يُجره مجزا در ســنجنده مـديس رابطه (19)

$B_{31}\left(T_{31}\right)=\tau_{31}(\theta) \varepsilon_{31} B_{31}\left(T_{S}\right)+\left[1-\tau_{31}(\theta)\right]\left[1+\left(1-\varepsilon_{31}\right) \tau_{31}(\theta)\right] B_{31}\left(T_{a}\right)$ $B_{32}\left(T_{32}\right)=\tau_{32}(\theta) \varepsilon_{32} B_{32}\left(T_{S}\right)+\left[1-\tau_{32}(\theta)\right]\left[1+\left(1-\varepsilon_{32}\right) \tau_{32}(\theta)\right] B_{32}\left(T_{a}\right)$

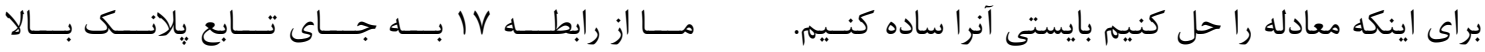

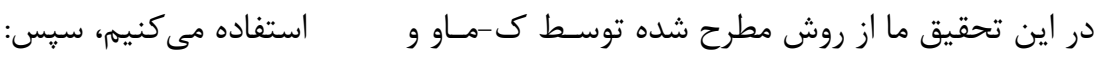
ديكران براى ساده سازى تابع يلانك استفاده مى منسينه. $B_{31}(T)=0.13787 T_{31}-31.65677, B_{32}(T)=0.11849 T_{32}-26.50036$ (IV) رابطه

$0.13787 \varepsilon_{31} \tau_{31} T_{S}=0.13787 T_{31}+31.65677 \varepsilon_{31} \tau_{31}-\left(1-\tau_{31}\right)\left[1+\left(1-\varepsilon_{31}\right) \tau_{31}\right]\left(0.13787 T_{a}-31.65677\right)-31.65677$ $0.11849 \varepsilon_{32} \tau_{32} T_{S}=0.11849 T_{32}+26.50036 \varepsilon_{32} \tau_{32}-\left(1-\tau_{32}\right)\left[1+\left(1-\varepsilon_{32}\right) \tau_{32}\right]\left(0.11849 T_{a}-26.50036\right)-26.50036$

براى راحتى محاسبه، ضرايب معادله مذكور را مىتـوان به صورت زير نوشت:

$$
\begin{aligned}
& A_{31}=0.13787 \varepsilon_{31} \tau_{31} \\
& B_{31}=0.13787 T_{31}+31.65677 \varepsilon_{31} \tau_{31}-31.65677 \\
& C_{31}=\left(1-\tau_{31}\right)\left(1+\left(1-\varepsilon_{31}\right) \tau_{31}\right) 0.13787 \\
& D_{31}=\left(1-\tau_{31}\right)\left(1+\left(1-\varepsilon_{31}\right) \tau_{31}\right) 31.65677 \\
& A_{32}=0.11849 \varepsilon_{32} \tau_{32} \\
& B_{32}=0.11849 T_{32}+26.50036 \varepsilon_{32} \tau_{32}-26.50036 \\
& C_{32}=\left(1-\tau_{32}\right)\left(1+\left(1-\varepsilon_{32}\right) \tau_{32}\right) 0.11849 \\
& D_{32}=\left(1-\tau_{32}\right)\left(1+\left(1-\varepsilon_{32}\right) \tau_{32}\right) 26.50036
\end{aligned}
$$




$$
T_{S}=\left(C_{32}\left(B_{31}+D_{31}\right)-C_{31}\left(D_{32}+B_{32}\right)\right) /\left(C_{32} A_{31}-C_{31} A_{32}\right) \quad(r \cdot)(\text { ر }
$$

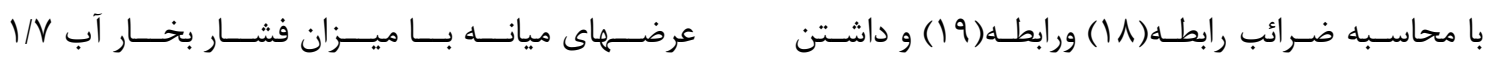

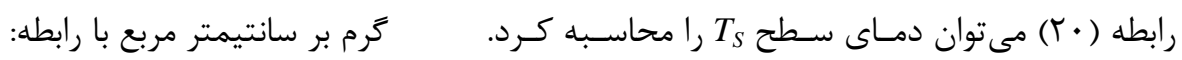

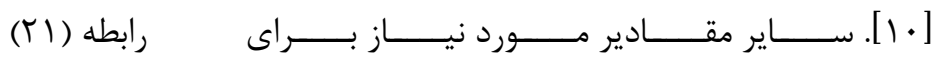

$\tau 31=2.89798-1.88366 \mathrm{e}-(\mathrm{w} /-21.22704)$

رابطه (YT)

$\tau 32=-3.59289+4.60414 \mathrm{e}(\mathrm{w} /-32.70639)$

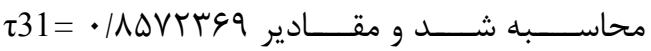

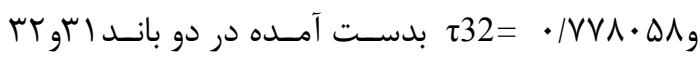
وارد مدل گرديد.به طور كلى، ڤارمترهاى محاسبه شـده

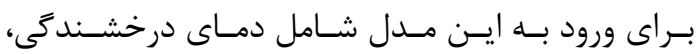
قابليت عبور جو و گسيلمندى مئباشد.
محاسبه دماى سطحى شامل گسيلمندى و قابليت عبور جو مىباشد. در مورد كسيلمندى از آنجايى كه هدف ما

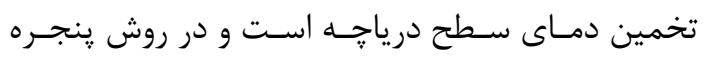

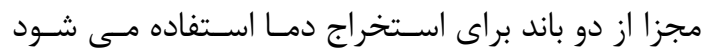

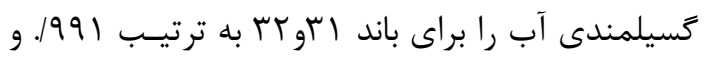
919 1. در نظر كرفته شده است.

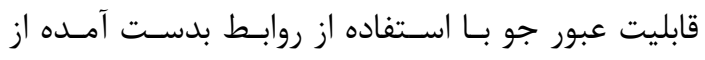

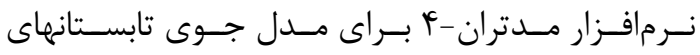

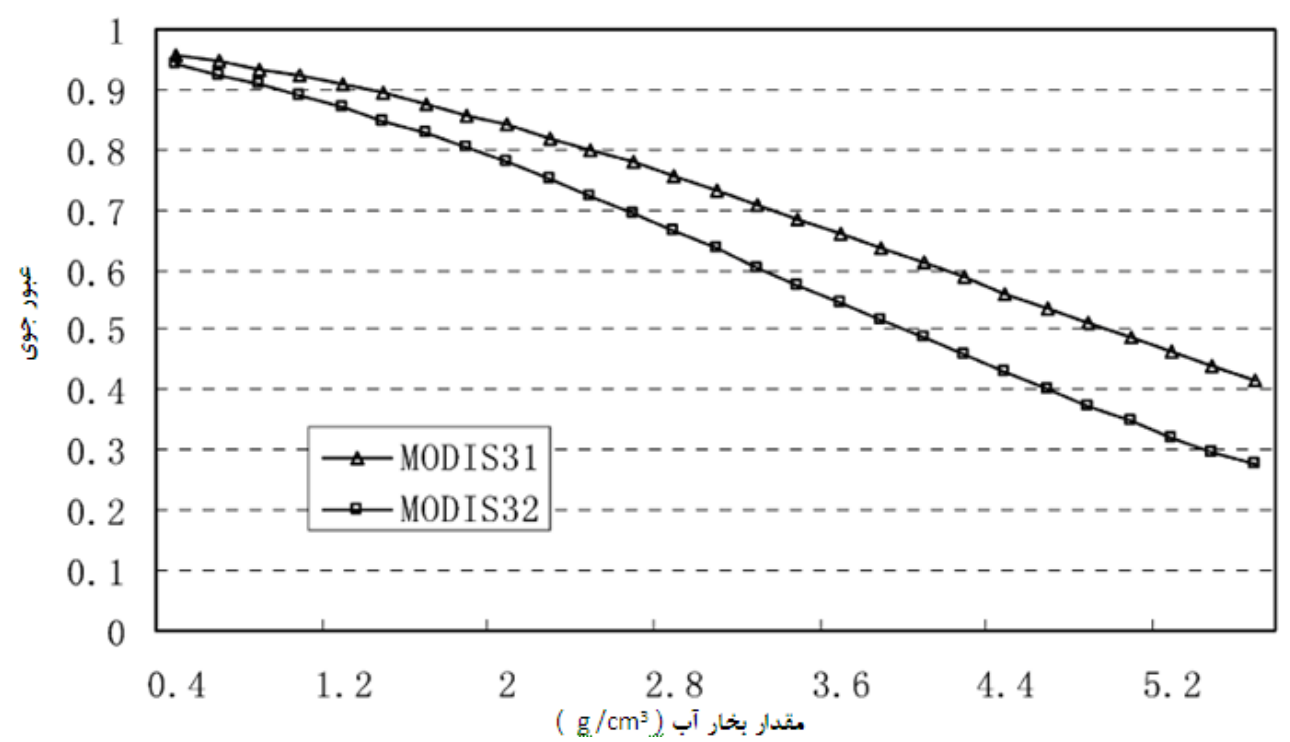

شكل r: نمودار ميزان قابليت عبور جوبراى مقادير مختلف بخار آب جو

•

9- موقعيت جغرافيايى

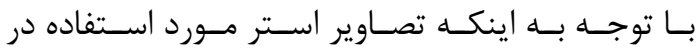

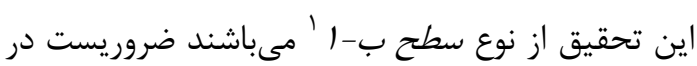

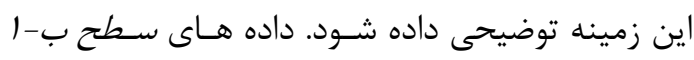

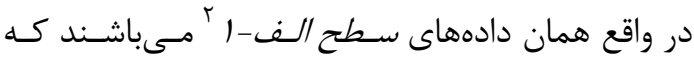
ضرايب و تصحيحات راديـومتريكى و هندسـى بـر روى

1 level 1B

2 level $1 \mathrm{~A}$
درياجه اروميه با وسعت متوسط حدود . ․ ميلـومتر

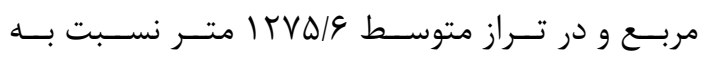

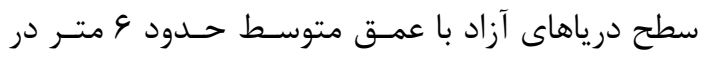

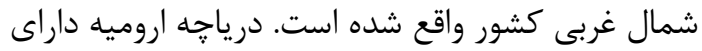
شكلى مسـتطيلى و شـمالى - جنــوبى مـى باشـد. طـول

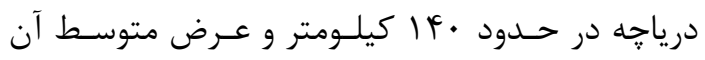

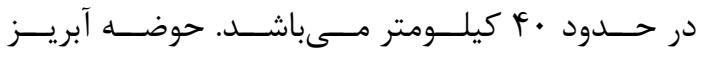

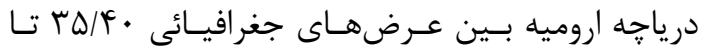




\section{V-1- عوارض بردارى ^ درياجه اروميه} فنآورى دور سنجى بهعنوان يك روش مقرون به صرفه

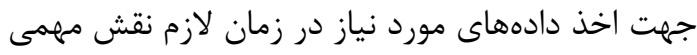

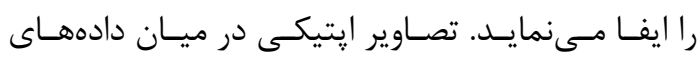
دور سنجى داراى مزاياى فراوانى است كه تفسير آسـان و در دسترس بودن بيشتر از آن جملهاند. بههمين علت

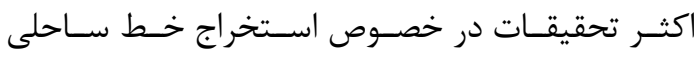

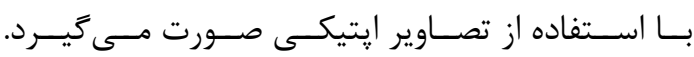
از طرف ديكر مشخصهاى طيفى آب به كونهايست كـهـ

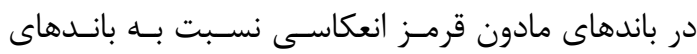

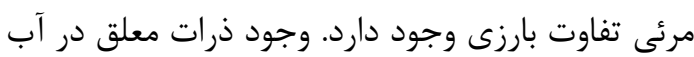

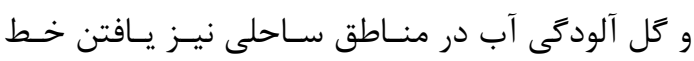

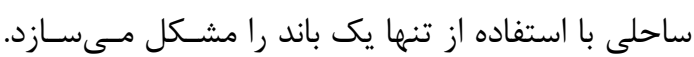

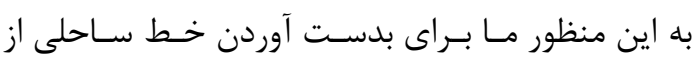

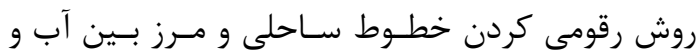
خشكى به صورت بصرى استفاده تا دقت جداسازى مرز

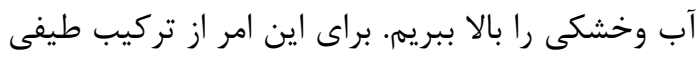

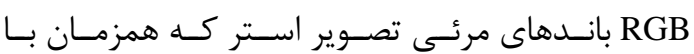

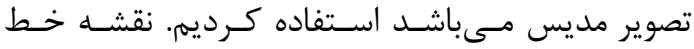

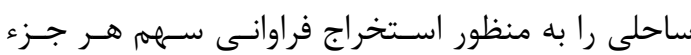

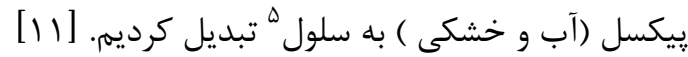
سه روش براى تعيين فراوانى اجزاى تصوير وجود دارد. ا - اجراى آناليز تركيب طيفى روى داده هاى راى راديانس

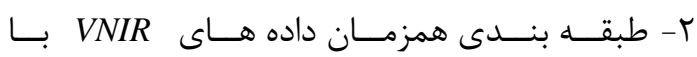
قدرت تفكيك بالا همانند آب و خشكى و تبديل بــــ فضاى قدرت تفكيك يايين

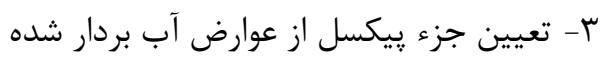

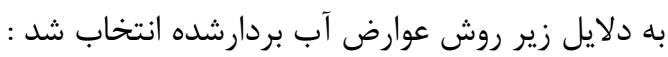
اين روش حتى هنگامى كه مـواد داراى دمـاى متفــاوت

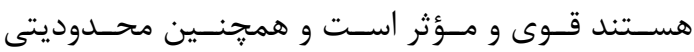

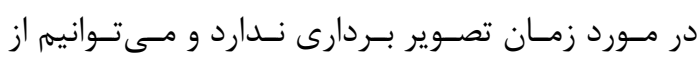
تصاوير روزانه و هم تصاوير شبانه استفاده كنيه.
آنها اعمال شده است. بطور كلى مسىــوان كَفـت اسـتر

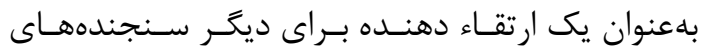

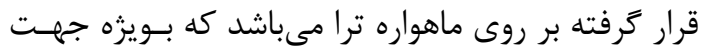

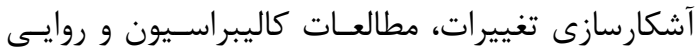

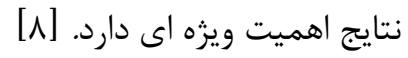

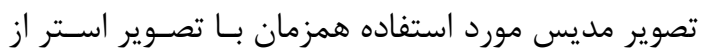

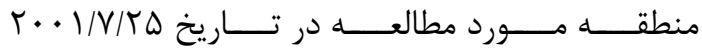
اخذ شده است. به خاطر يوشش گسترده تصوير مـديس

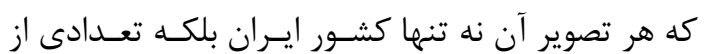
كشورهاى همسايه را در بر مى گيرد ابتدا با به كاركيرى

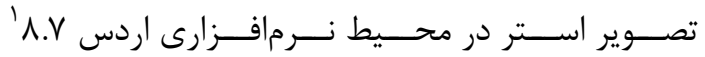

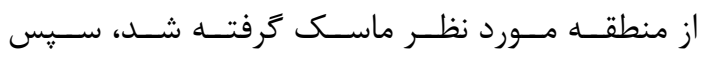

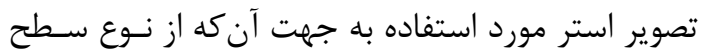

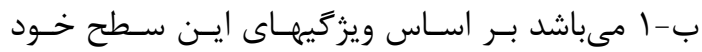

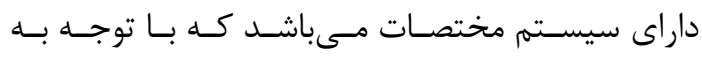

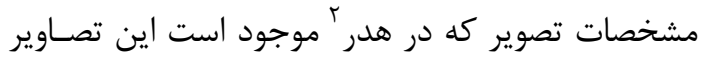

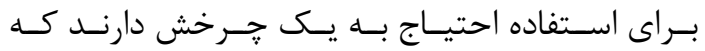

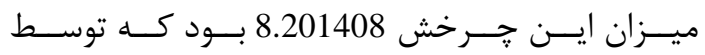

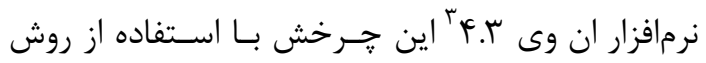

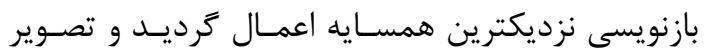

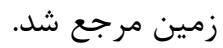

\section{V- استخراج دماى زير ييكسل تصوير مديس}

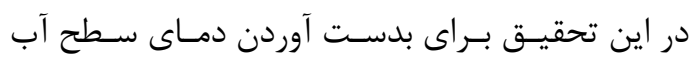

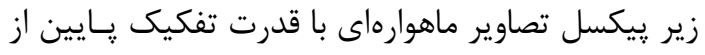

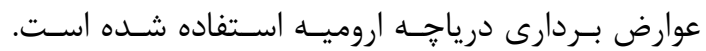

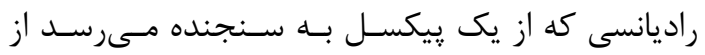
مواد مختلفى تشكيل شده است كه در اين تحقيـق مـا

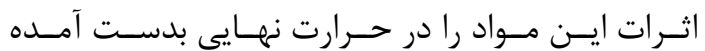
بررسى كرديم و سهم حرارت هر جـزء تشـكيل دهنــده

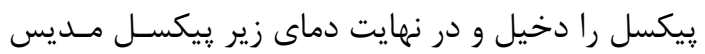

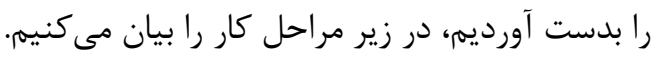

1 ERDAS IMAGINE 8.7

2 Header

3 ENVI 4.3 
ايسـن امـر بـا اسـتفاده از بــردار تهيـهـه شـده از سـاحل و

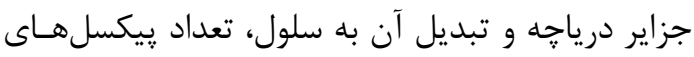

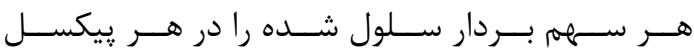

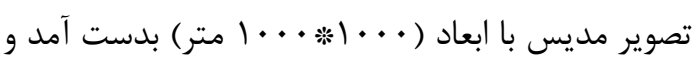
با شمارش تعداد هر جزء در يِيكسل مديس و تقسيم بر

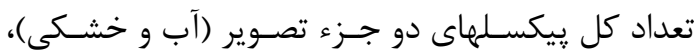

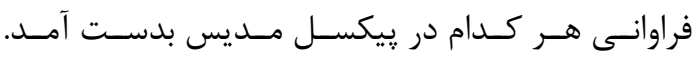

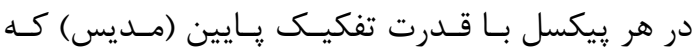

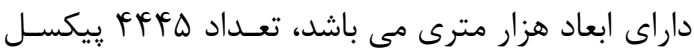

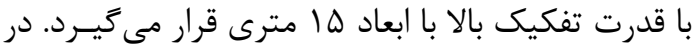

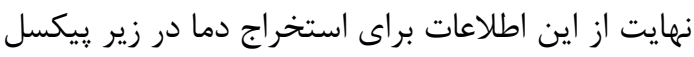
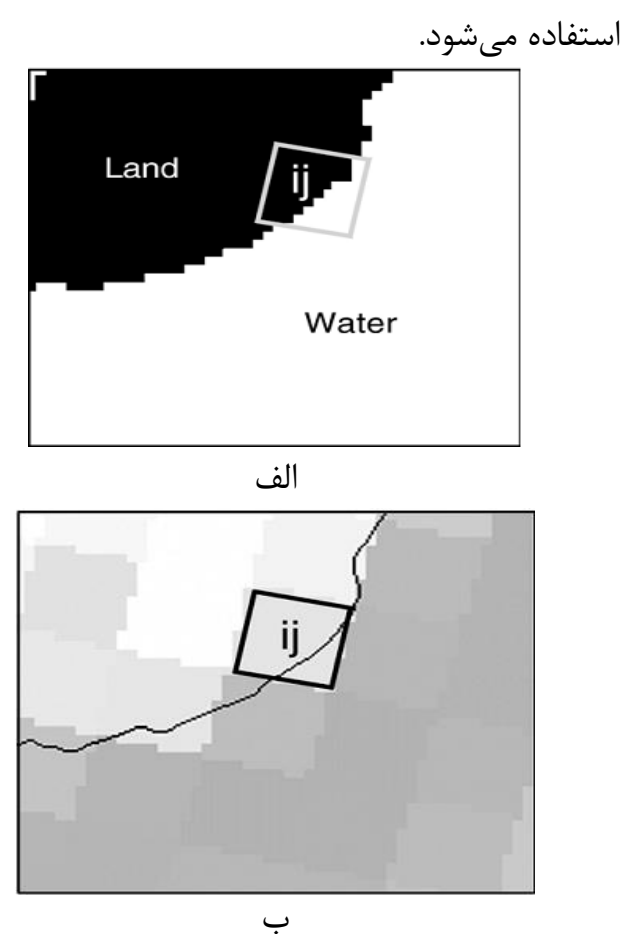

شكل (F): الف) داده هاى بردارى سلولى شده ب ) تصوير راديا نس مديس

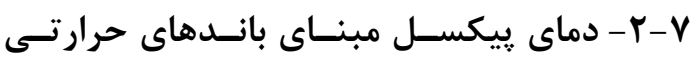

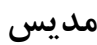

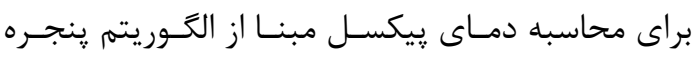
مجـزا يِيشـنهادى توسـط مـائو' اسـتفاده كـرديم [ [1].

$1 \mathrm{Mao}$

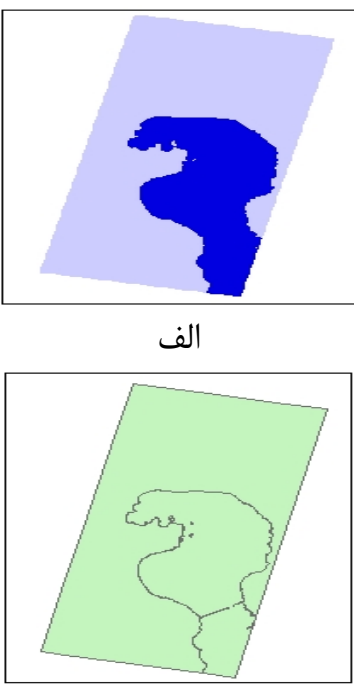

$\varphi$

شكل (Y): الف - بردارخط ساحلى سلولى شده

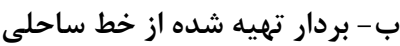

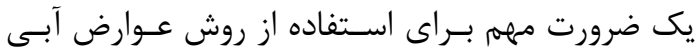
بردار شده اين است كه نياز به زمين مرجع كردن دقيق

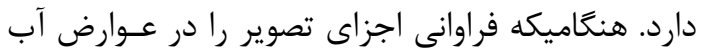

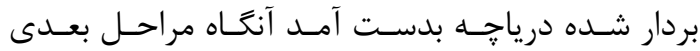

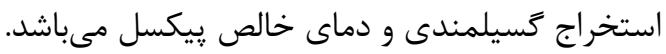
براى محاسبه دماى ييكسل هاى ناخالص تصوير مـديس به سهم اجزاى تشكيل دهنده ييكسلها نيازمند هسـتيمم كه عدم دقت تصـحيح هندسـى تصـاوير مـديس باعـث بدست آمدن دقت پايين در سهرم جزء هر ييكسـل (آب

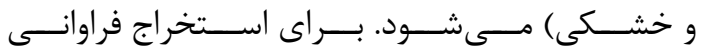
اجزاى بيكسل لازم است مراحلى را انجـام داد، نخسـت

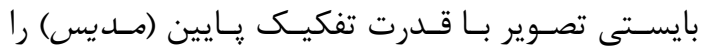

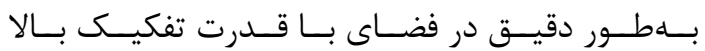
زمين مرجع نمود سـيس بـر اسـاس دادههـاى بـردارى

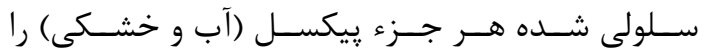
در ييكسل با قدرت تفكيك يايين (مديس) بدست آرود و با شمارش تعداد ييكسلمهاى آب و خشـكى در تصـوير

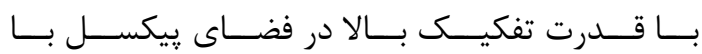

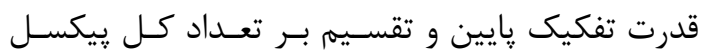
خشكى وآب موجود در ييكسل با قدرت تفكيك يـايين

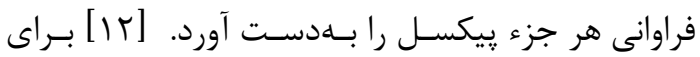


برآورد خرد-يقيكسلى دماى آب درياجه اروميه...

يرويز ضيائيان فيروز آبادى و همكار

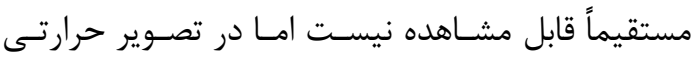

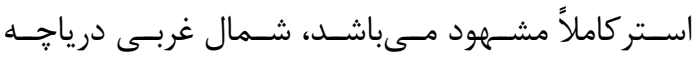

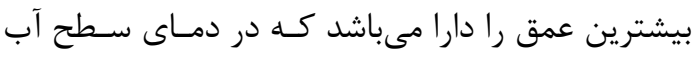

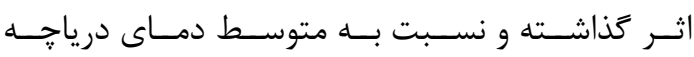

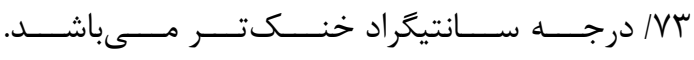

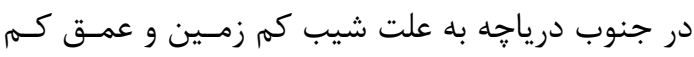
آب دماى بيشترى مشاهده شد. دماى جزايرى كه ابعـاد

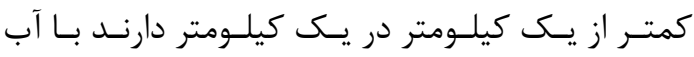
اطراف آن مخلوط شده و دمـاى آب را افززايش دادهانـد

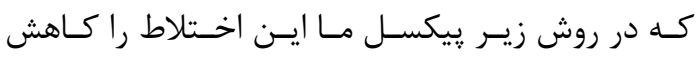
دادهايم. در زير نقشه دمايى مديس قابل مشاهده است.

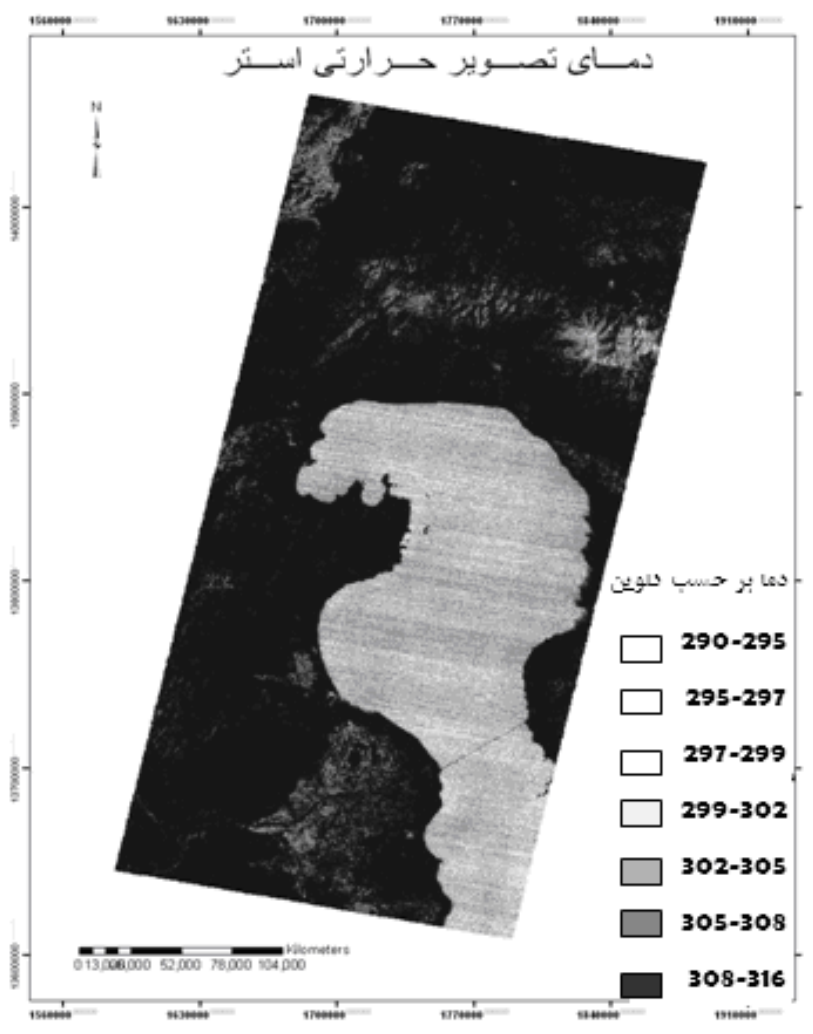

روش پيكسل مبنا در تصاوير با قدرت تفكيك يايين دما

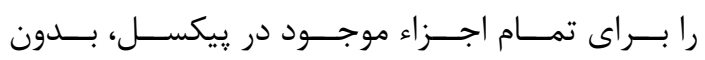

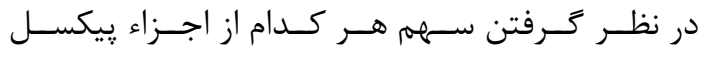

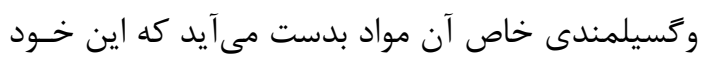

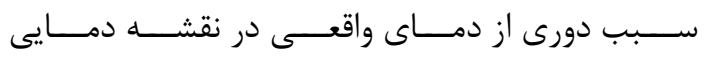

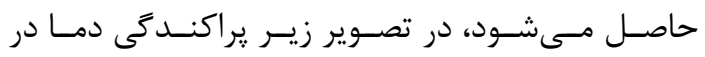

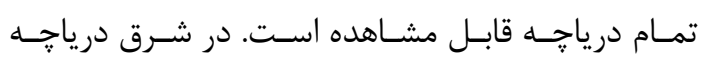

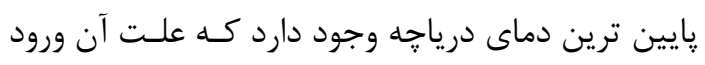

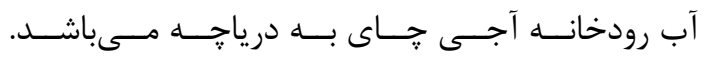

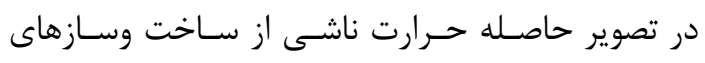

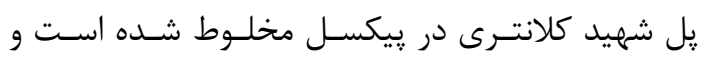

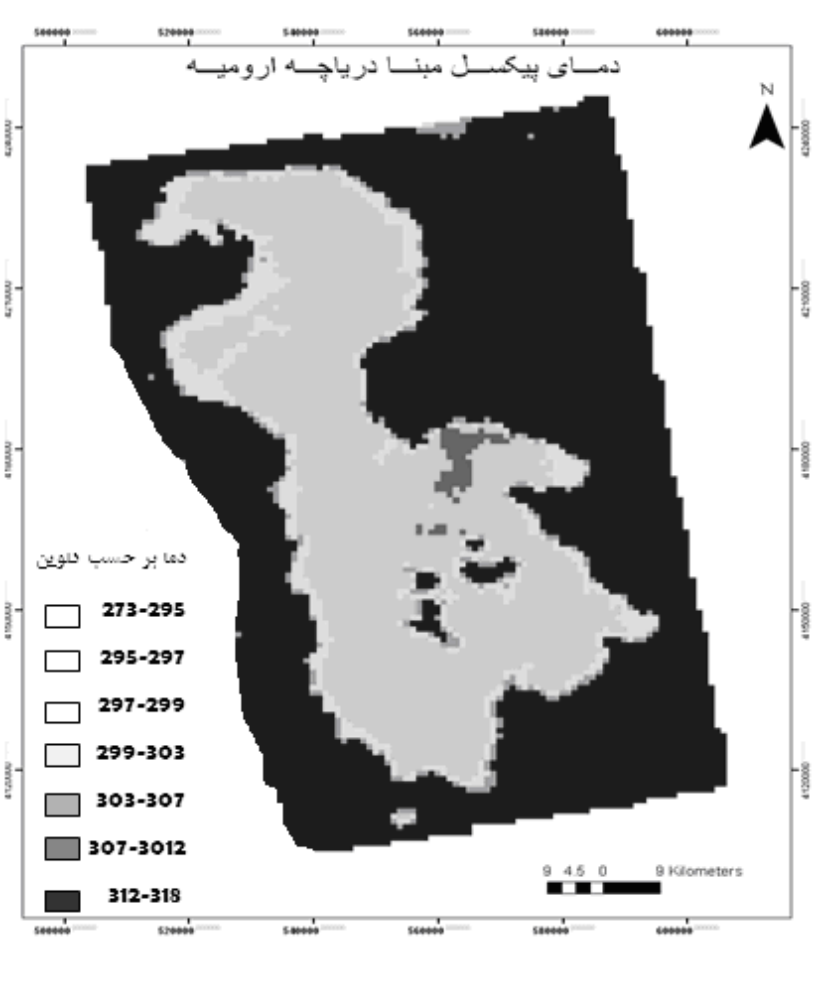

شكل (ه): دماى پيكسل مبناى تصاوير MODIS و ASTER درياجه اروميه

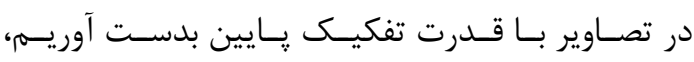

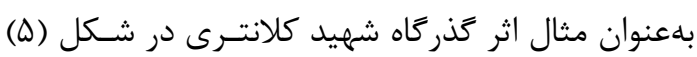
قابل مشاهده نيست اما مى بينهم كه ايسن اثـر بـا اعمـال

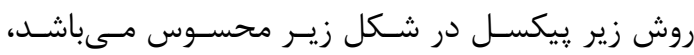

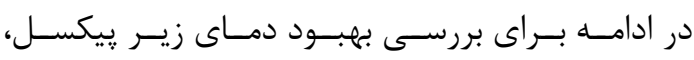

د-V - دماى زير קييكسل باندهاى حرارتى مديس

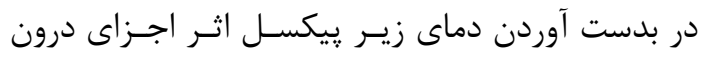

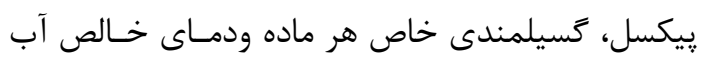

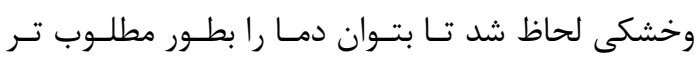


هدف اين تحقيق بررسى دماى زيــر بيكسـل بــوده لــذا

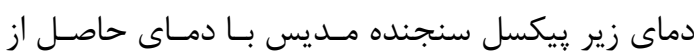
تصوير حرارتى استر مقايسه شد. ميانخين دما در تصوير

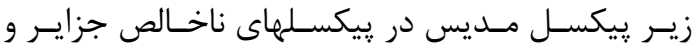

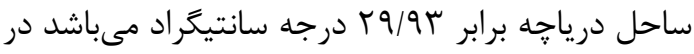

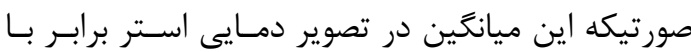

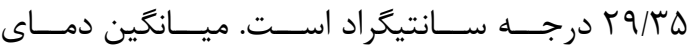
يِيكسل مبناى مناطق موردنظر در تصوير استر برابـر بـاــا

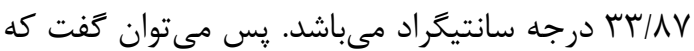
خطاى ميانگَين دماى زير קيكسل تصوير مديس و استر

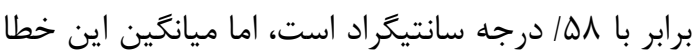

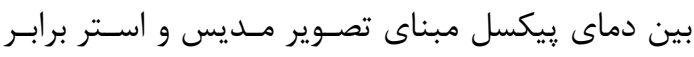

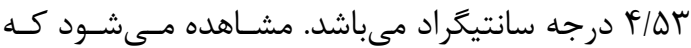

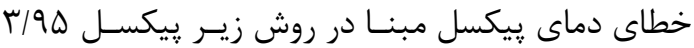

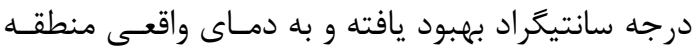

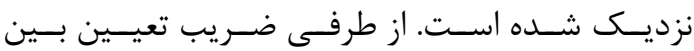

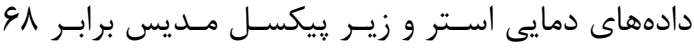
درصد مىباشد كه اين نشان مىدهد كه متغيير وابسـته

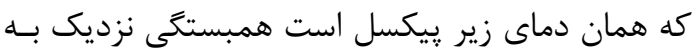

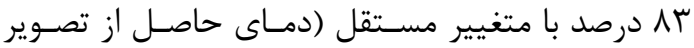
استر) دارد در صورتيكه اين ضريب بين دمـاى ييكسل

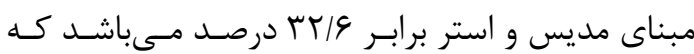
همبستخى DF درصدى با متغيير مستقل (دماى حاصل

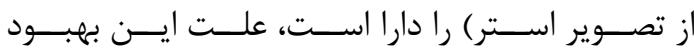

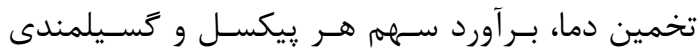

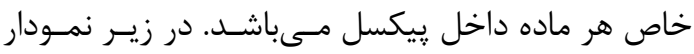
ضريب تعيـين بـراى دماهـاى بدسـت آمــده از تصـاوير

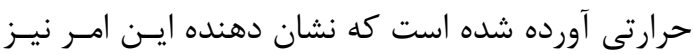

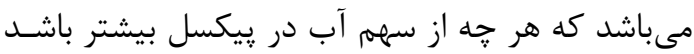

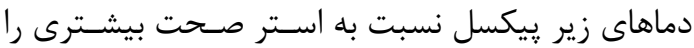
داراست. - ماست

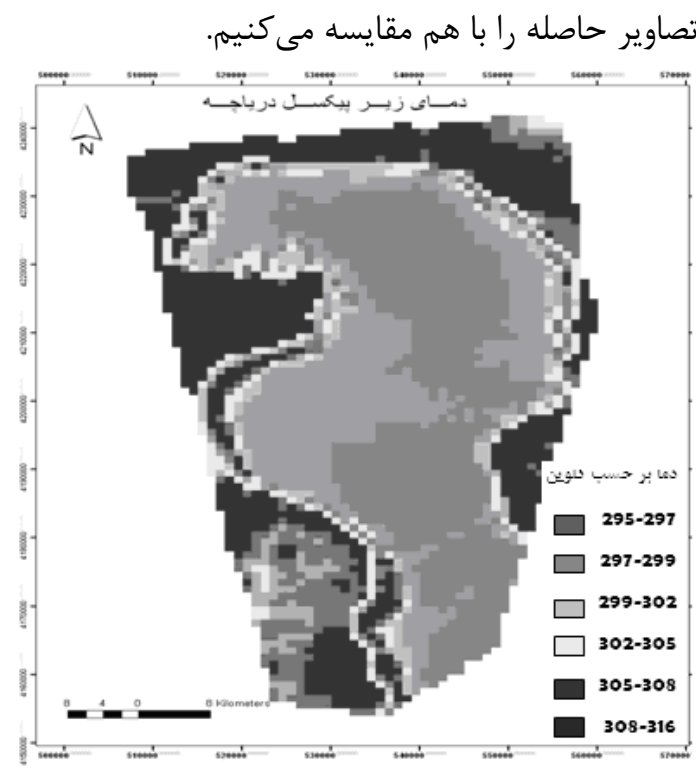

شكل (申): دماى زير ييكسل تصوير MODIS درياجه اروميه

1 - نتيجه خَيرى

اندازهيرى دماى زمين متناسب با مقياس ويكسل هـاى تصوير مديس (يـك كيلـومتر در يـك كيلـومتر) بسـيار

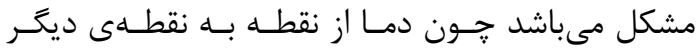

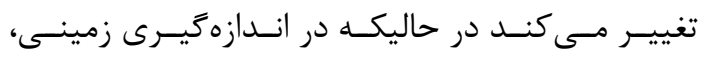

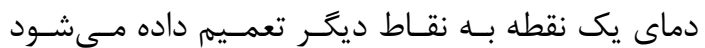

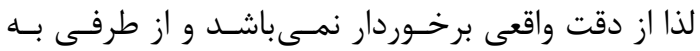

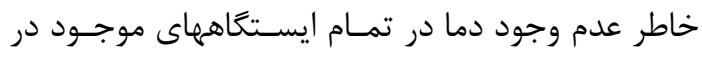

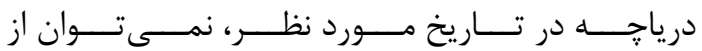

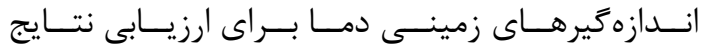

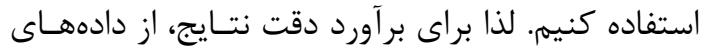
استخراج شده دماى حاصل از تصوير استر كه همزمـان

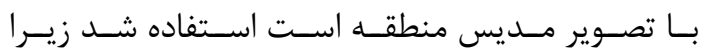

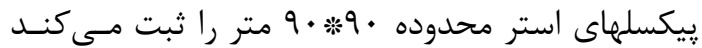

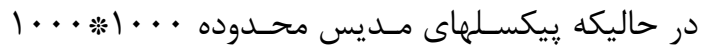

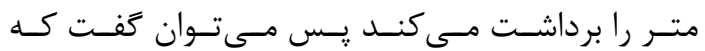

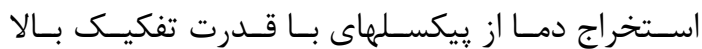

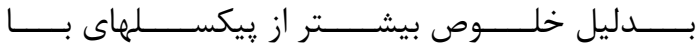

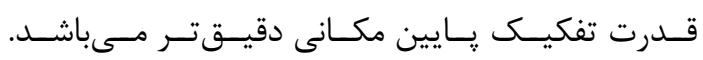




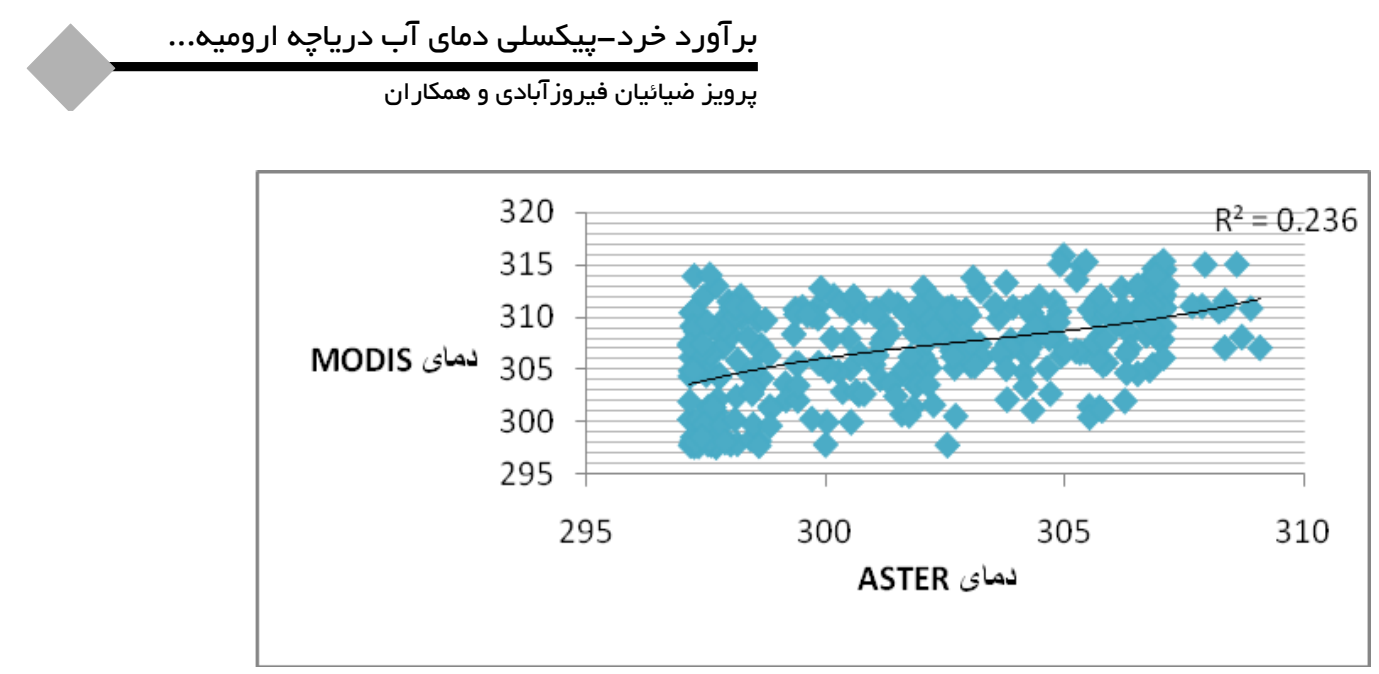

شكل (V): نمودار ضريب تعيين بين دماى ييكسل مبنا برحسب كلوين MODIS و ASTER

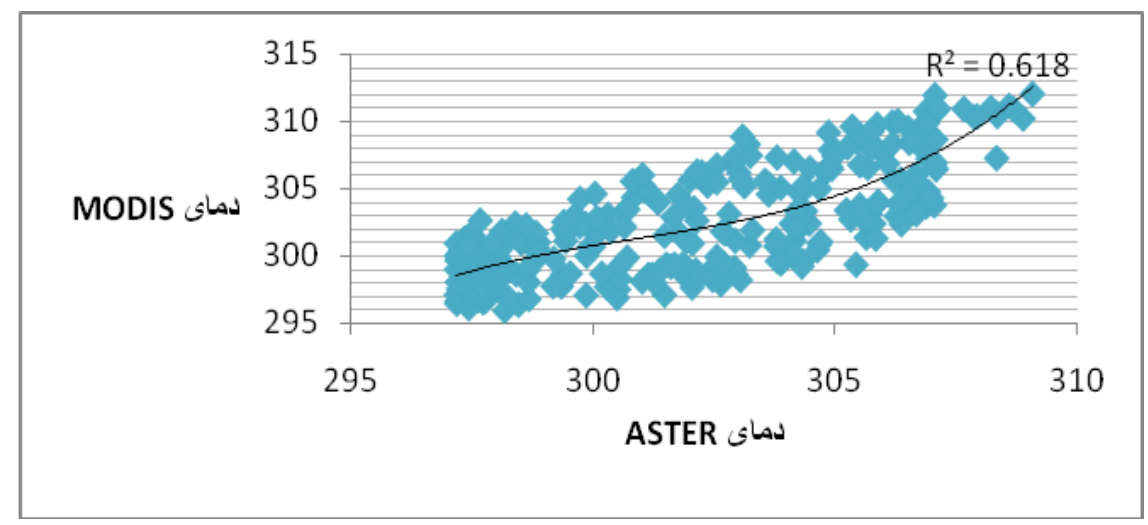

شكل (^): نمودار ضريب تعيين بين دماى زير پييكسل برحسب كلوين MODIS و ASTER

[1] Kay, J. E., Kampf, S. K., Handcock, R. N., Cherkauer, K. A., Gillespie, A. R., \&Burges, S. J. (2005). Accuracy of lake and stream temperatures determined From atmospherically corrected thermal-infrared imagery. Journal of the American Water Resource Association, 41, 1161-1175.

[2] Szymanski, J. J., Borel, C. C., Harberger, Q. O., Smolarkiewicz, P., \& Theiler, J. P. (1999). Subpixel temperature retrieval with multispectral sensors. SPIE, Vol. 3717.(pp. 38-46) Orlando, FL, USA: Algorithms for Multispectral and Hyperspectral Imagery

[3] Gowda, H., Manikiam, H. and Chandrasekhar, M.G. 1993. Remote sensing for marin fisheries development in INDIA. Journal of Remote sensing of Environment 1375-1405

[4] Sur, H. and Ozsoy, E. and Ibrayer, R2000.Satellite derived flow characteristic of the Caspian sea in: satellite oceanography and society. Vol 16, pp:294-312

$$
9
$$

[5] Oesch, D., Hauser, A. and Wunderle, S. 2003. Operational mapping of lake surface temperature in the Alps using NOAAAVHRR data: intercompasion of different lakes. Remote sensing research group, Department of Geography, university of Bern, Switzerland.

[6] Zobeiri.M and Majd.A,1999, fundamental remote sensing and with application to natural resources, Tehran university press.

[7] Karimi.M, 2001, using images AVHRR in Preparation map temperature in SST to Gulf Persian, MS Tarbiat modares

[8] Qin Z. \& Karnieli A. \& Berliner P. (2001). A Mono-Window Algorithm For Retrieving Land Surface Temperature From Landsat TM Data And ItsApplication To The IsraelEgypt Border Region. International Journal Of Remote Sensing, Vol 22, No 18, Page 
3719-3746.

[9] Liang, S. (2001). An optimization algorithm for separating land surface temperature and emissivity from multispectral thermal infrared imagery. IEEE Transactions on Geoscience and Remote Sensing, 39(2), 264-274.

[10] K. Mao, Z. Qin, J. Shi, and P. Gong, 2005, A practical split-window algorithm for retrieving land-surface temperature from MODIS data, International Journal of Remote Sensing, Vol. 26, No. 15, 31813204

[11]Jupp, D.L.B., 1988, "Background and extensions to depth of penetration (DOP) mapping in shallow coastal waters ". Proceeding of the symposium on remote sensing of coastal zone, Gold Coast, Queensland, September 1988, IV.2.1IV.2.19.

[12] Gabriel I.sentlinger, Simon J. Hook(2008), Sub-pixel water temperature estimation from thermal-infrared imagery using vectorized lake features. Remote Sensing of Environment 112 1678-1688 


\title{
Subpixel water temperature estimation of Urmia lake using un mixing approach of thermal infrared satellite images
}

\author{
Parvize ziaeean*1 ${ }^{1}$, Manochere Faragzadeh ${ }^{2}$, Ali Jafare mosivand ${ }^{3}$, Mahmood omidali ${ }^{4}$ \\ 1. Associate professor kharazmi university \\ 2. Associate professor tarbiat modares university \\ 3. Dr.student,Delft industrial university, netherlands \\ 4. Postgraduate tarbiat modares university
}

\begin{abstract}
Measuring water temperature is an important environmental index in order to study narrow channels, rivers, and lakes. Also, it has important role in environmental and water resources management. Although high resolution data can provide better estimation of surface water temperature, but due to their low temporal resolution, they have less applicability. In contrast, low spatial resolution data like Modis images, due to their high temporal resolution (several times a day), is more suitable for estimating parameters of dynamic phenomenon such as water temperature. In order to use low resolution images, a sub-pixel unmixing technique was developed and tried on Urmia lake waters. This approach leads an improvement in accuracy of water temperature maps derived from vectors water features. After derivation of each image fractions for water and land and calculation of emissivity of each fraction, water temperature was estimated using Split Window algorithm. Then temperature water sub-pixel was compared to the temperature map obtained from ASTER thermal bands. Standard error between the images was estimated to be 0.58 centigrade, which is a favorable result.
\end{abstract}

Key words: Water temperature, MODIS, ASTER, Pixel-base, Sub-pixel

Correspondence Address: Department of Geography kharazmi University Mofateh Ave. Tehran, Iran. Tel: +98 9123903621 Email: ،emails:rsgis1000@yahoo.com 